Analysis

\section{Towards a green economy through innovations: The role of union involvement ${ }^{\text {th }}$}

\author{
Davide Antonioli ${ }^{\mathrm{a}}$, Massimiliano Mazzanti ${ }^{\mathrm{b}, *}$ \\ ${ }^{a}$ Department of Management and Business Administration, University of Chieti-Pescara, Italy \\ ${ }^{\mathrm{b}}$ Department of Economics and Management (DEM), University of Ferrara, Italy
}

\section{A R T I C L E I N F O}

Received 5 November 2015

Received in revised form 12 August 2016

Accepted 4 September 2016

Available online $\mathrm{xxxx}$

\section{JEL classification:}

$\mathrm{O} 30$

033

L6

$\mathrm{J} 5$

Keywords:

Environmental innovation

Unions

Firms

Manufacturing

\section{Article history:}

\begin{abstract}
A B S T R A C T
In this paper, we address the overlooked issue of whether and how industrial relations might play a role in the process of greening the economy, primarily through the levers of innovation adoption and organisational change. We address our objective econometrically, assessing the quality of industrial relations as a driver of environmental innovation adoption, through the use of micro-data on manufacturing firms. The results yield two interesting main findings: being a unionised firm is not associated with the adoption of environmental innovation; however, when we consider the industrial relations climate, we observe a positive relationship between a cooperative industrial relations climate (union involvement) and the propensity to introduce environmental innovation. Two models are relevant: a managerially oriented model (unions are informed) and a participatory model (unions bargain on innovation adoption). The contents of environmental innovations are also important: union involvement is more relevant for adopting more complex and radical innovations to abate $\mathrm{CO}_{2}$ and EMS and ISO practices.
\end{abstract}

(C) 2016 Published by Elsevier B.V.

\section{Introduction}

The XXI Conference of the parties of United Nations Framework on Climate Change (UNFCCC) ended in December 2015 with some new directions for countries and economic agents that might be taken to cope with Green House Gases (GHG) emissions. Though the very diversified static and dynamic benefits/costs assessments across countries prevented the Conference from reaching a global/country based agreement on emission reductions, the architecture is framed around 'Intended nationally determined contributions': it identifies governments actions towards medium-long term commitments. These actions may include innovation-oriented

\footnotetext{
it This paper is based on work carried out in the CECILIA2050 research project, funded by the European Union under the 7th Framework Programme for Research (grant agreement n 308680, http://www.cecilia2050.eu). It has benefited considerably from discussions with numerous partners in the CECILIA2050 research consortium. Moreover, we would like to thanks unions representatives and union advisors both at EU, Italian and local level for sharing their precious experience and information. The usual disclaimers apply.

* Corresponding author.

E-mail addresses: davide.antonioli@unich.it (D. Antonioli), massimiliano.mazzanti@unife.it (M. Mazzanti).
}

actions and strategies (for updates see climateobserver.org/open-andshut/ind). As for the implementation of climate policies (e.g. mission trading), the climate policy architecture will be more and more based upon bottom up efforts by countries and regions. This framework, which needs a good enforcement and monitoring effort, is possibly the only feasible outcome. We note it gives more chances and room for actions to countries, regions - and to various agents and stakeholders - to flexibly define abatement strategies in order to minimise costs and enhance economic/innovation outcomes. The role of industries, unions and other institutions and networks is widened, as well as their responsibility towards climate strategies. The role of regional entities is further enhanced in 'federal' countries.

Within this framework the challenges faced by trade unions in recent years, primarily due to the economic crisis that continues to impact EU labour markets (there are about 21.5 million unemployed men and women at present in the EU-28), have likely diverted some union 'energy' away from green issues, through the diffusion of collective bargaining on environmental topics, towards issues concerning the adverse effects of the economic crisis on labour markets and workers, e.g., the Framework for Action on Youth Employment (http://www.etuc.org/r/20). The Italian case is an example. The disruptive power of the crisis could also have undermined the wellestablished and structured social dialogue that has matured in recent 
decades among EU social partners ${ }^{1}$ Unions are among those crucial actors in the implementation of reforms and measures to cope with the challenges imposed by the crisis (Eurofound, 2009). Moreover, when green arguments and industrial relations are jointly considered, the main challenge for unions ${ }^{2}$ becomes how to integrate green and labour issues in the post-recession scenario (Uzzell et al., 2011).

Because unions play a relevant role in shaping both the EU policy agenda and, at the micro level, in influencing firms' adoption of environmental innovations (EIs, henceforth), we are interested in investigating the capacity of unions to influence the adoption of EIs (see Cainelli et al., 2012, for analyses on internal and external firm factors), which is a critical issue concerning the deployment of actual and future policies intended to fulfil the 2050 energy roadmap objectives. Els are crucial for decoupling economic growth from environmental pressures (Borghesi et al., 2015a,b; EEA, 2014). We distinguish the effect of union involvement in firms' decisions with respect to the type of EI pursued, namely the degree of ' public good' content in the EI. Corradini et al. (2014) and Gilli et al. (2014) stress that $\mathrm{CO}_{2}$-abating innovations are characterised by a larger share of public good output with respect, for example, to energy efficiency, the ' rents' of which are generally much more appropriable by firms. In addition, regarding the ' radicalness' of an innovation, it is worth assessing the differences among more radical EIs, e.g., $\mathrm{CO}_{2}$ abatement, EMS/ISO, and end-of-pipe innovations (Carrillo-Hermosilla et al., 2010) (emission abatement). We disentangle innovations oriented at reducing global public bads $\left(\mathrm{CO}_{2}\right)$ and innovations that increase ' environmental efficiencies', which provide more appropriable rents in production (Mazzanti and Zoboli, 2009). Energy and materials feature a larger share of appropriable economic returns (Corradini et al., 2014). Regarding public goods such as $\mathrm{CO}_{2}$, it is inherent a strong role played by spillovers and cooperation with other agents: the lower the private component in public goods, the more difficult to find solutions relying on internal resources. External sources of innovation/information play a stronger role. In addition, it is worth stressing that $\mathrm{CO}_{2}$ is not reduced by end of pipe technological solutions. The reduction of $\mathrm{CO}_{2}$ emissions and of $\mathrm{GHG}$ is more complex and implies a full restructuring and reorganisation of firm's assets and aims (Marin and Mazzanti, 2013). The involvement of other firms, stakeholders and unions capabilities could then be more relevant. Hence, unions involvement might be more relevant and necessary when Els are highly radical and complex.

This work is structured as follows. The next section provides a review of the extant literature. In the third section, we specify the main research hypotheses and the applied methodology. The following section is devoted to the results description. The final section provides concluding remarks.

\section{Background Literature}

Do unionised firms, and among them those with good industrial relations (firm level unions involvement), provide more environmental benefits through the EIs adoption?

\footnotetext{
1 Here, we refer to trade unions and employers or their representative organisations. The social partners are involved in the social dialogue, which can also be considered a tripartite dialogue involving a third partner: the government. Although a promising topic for future research, we are not strictly interested in the tripartite social dialogue, as our focus will be on union involvement in managerial decisionmaking processes, focusing our attention on the micro-level dialogue between management and workers through the mediation of firm-level union representatives.

2 A series of unstructured interviews to union members belonging to different union confederations, both at European and Italian levels were conducted. From these interviews to union representatives and policy advisers we were able to extract highlights and considerations of interest for the comprehension of the complex phenomenon represented by the relation between green and labour market issues in a context of a (Just)transition towards a low carbon economy.
}

From a theoretical side, the usual assumption made on the linkage between unions and innovation is to regard unions as an element of the economic system that may, positively or negatively, influence a firm's innovative capacity. The positive or negative impact can be due, in the words by Freeman and Medoff $(1979,1984)$, to the ' two faces of unionism'. Unions act both in accordance to their ' monoply face', which is usually associated to the negative effects of unionism, and in accordance to their 'collective voice', which highlights the value enhancing role of unions (Hirsch, 2004). The 'monopoly face' label stands for the possibility, for unions, to exploit their monopoly power on labour in order to rise wages and extract rents from firms' extra-profits, while the 'collective voice' label stresses the role of unions as a labour market institution that may favour innovation adoption, supporting firm development. Hence, on the one hand, unions may generate misaligned incentives, according to the conceptual framework depicted by several scholars from the Freeman and Medoff works onwards, which are analysed using conceptual tools belonging to (neo)classical economic theory.

\subsection{The Potential Negative and Positive Impact of Unions on Innovation Activities}

Bradley et al. (forthcoming) put forward three main reasons underpinning the 'monopoly face' of unions. First, they could generate hold up problems (Grout, 1984). The rent-seeking behaviour of the union has the aim of capturing returns from investment in tangible and intangible capital, but also from investments in innovation, reducing management's incentive to invest. As Hirsch (2004) clearly illustrates, if unions 'tax' investments in long-lived capital, R\&D and other innovative activities, then the firms, internalising this unions behaviour, tend to reduce investment in such activities and capital. In particular, as innovative activities are concerned, the degree of appropriability of the quasi-rents associated to the innovation investments will guide the firms investments decision. Second, because unionisation may reduce the probability of dismissal, even in the presence of shirking, the latter would be 'encouraged' to some extent, thereby reducing productivity and lowering the innovation propensity of workers. Finally, as unions tend to reduce the gaps in wages among workers, the most talented workers would choose non-unionised firms to maximise the wage gains secured by their abilities. More generally, the wage premium causes distortions in relative factor prices, which in turn produce a dead-weight welfare loss (Hirsch, 2004).

The 'collective voice' (or institutional response face) of unions has positive implications for the firm performance to the extent that the management is responsive and supportive to union voice (Freeman and Medoff, 1984). Unions, as an element of the governance structure of firms, may positively influence innovation activities because, protecting workers against dismissal, trigger innovation activities, since employees are less concerned by any risky and uncertain innovation processes that the management intends to pursue. Moreover, unions are receptive towards organisational changes that aim to ameliorate the workforce well-being and help retain trained staff (Doucouliagos and Laroche, 2013), which represent firms specific human capital asset that may improve the absorption capacity of the firm towards new technologies.

\subsection{The Role of Unions Involvement on Innovation Activities}

Although the above arguments on the effect of unionisation on innovation are insightful, we contend that in empirical works there is a missing link between unionisation and innovation that is too often neglected: the firm-level dialogue between management and unions, which is a crucial factor for the deployment of the positive effects of the unions 'collective voice'. This dialogue, which can be 
Table 1

Union involvement in the decision-making process along six dimensions of innovation (402 obs.).

\begin{tabular}{|c|c|c|c|}
\hline Innovation dimension & Degree of involvement & Freq. & $\%$ \\
\hline \multirow{3}{*}{ Organisational innovations } & No involvement & 50 & 12.44 \\
\hline & Information & 229 & 56.97 \\
\hline & Consultation & 83 & 20.65 \\
\hline \multirow{5}{*}{ Training } & Bargaining & 40 & 9.95 \\
\hline & No involvement & 56 & 13.93 \\
\hline & Information & 219 & 54.48 \\
\hline & Consultation & 96 & 23.88 \\
\hline & Bargaining & 31 & 7.71 \\
\hline \multirow{3}{*}{ Technological Innovation } & No involvement & 61 & 15.17 \\
\hline & Information & 237 & 58.96 \\
\hline & Consultation & 77 & 19.15 \\
\hline \multirow{5}{*}{ ICT implementation } & Bargaining & 27 & 6.72 \\
\hline & No involvement & 82 & 20.4 \\
\hline & Information & 220 & 54.73 \\
\hline & Consultation & 73 & 18.16 \\
\hline & Bargaining & 27 & 6.72 \\
\hline \multirow{3}{*}{ Environmental innovation } & No involvement & 74 & 18.41 \\
\hline & Information & 224 & 55.72 \\
\hline & Consultation & 77 & 19.15 \\
\hline \multirow{5}{*}{ Internationalisation strategies } & Bargaining & 27 & 6.72 \\
\hline & No involvement & 96 & 23.88 \\
\hline & Information & 211 & 52.49 \\
\hline & Consultation & 70 & 17.41 \\
\hline & Bargaining & 25 & 6.22 \\
\hline
\end{tabular}

regarded as the unions' involvement ${ }^{3}$ in the decision-making process at firm level may be considered a crucial moderating factor, the particular relevance of which emerges when it makes unionisation a favourable element for innovation. As pointed out by Doucouliagos and Laroche (2013) there are several moderating factors (e.g. labour market regulation) that explain the ambiguous findings of the empirical literature on the effect of unions on innovation (Menezes-Filho and Van Reenen, 2003; Freeman, 2007; Laplante and Harrisson, 2008; Walsworth, 2010; Fang and Ge, 2012; Chun et al., 2015).

In the vast literature on the determinants of innovation, the components of the institutional context have been widely studied, especially by scholars investigating national systems of innovation (see among others: Groenewegen, 2006; Sharif, 2006; Guan and Chen, 2012) or regional systems of innovation (e.g.: Cooke et al., 1998; Doloreux, 2002). One of these components is the system of industrial relations ${ }^{4}$ and its characteristics that may influence one of the firm level factors, namely unions involvement, which can turns the unions influence on innovation from negative to positive. In line with Metcalf (2003), we argue, as stated above, that when unions and management have non-adversarial relations and establish win-win strategic behaviour in pursuing common goals and gains, then the union's presence at the firm level can spur innovation activity instead of hampering it (Metcalf, 2003). Cooperation, consultation and bargaining between management and unions on relevant issues, including innovation strategies, create a participatory industrial relations climate that may foster and nurture innovation. Therefore, it can be argued that the impact of unions on innovation is mediated by their involvement in the firm's governance structure; however, the impact must be empirically verified, given the absence of univocal theoretical insights.

3 An important role can also be assigned to the direct employees involvement as shown by Hanna et al. (2000).

4 We do not focus our attention on factors external to the firm in this work, but we acknowledge their relevance. The study of the role of stakeholders and external factors may be the subject of future works related to the topic of the present paper.

\section{Research Questions and Quantitative Evidence}

\subsection{Setting the Research Questions}

Based on the previous literature, it is interesting to test whether unionisation is related to the propensity to adopt Els, 363 where environmental innovation assumes, in accordance to a 364 pretty consolidated literature, the following definition: it is an 365 innovation which benefits the environment and contributes to 366 environmental sustainability (Rennings, 2000), laxly including non- 367 intentional environmental innovation and innovation strategies 368 producing environmental benefits (Triguero et al., 2013; Kemp 369 and Pontoglio, 2011) ${ }^{5}$. As pointed out by the literature (we here 370 mainly refer to 'economics and management' oriented survey based 371 empirical papers (Horbach et al., 2012; Cainelli et al., 2012; Borgh- 372 esi et al., 2015a; Triguero et al., 2013; Kesidou and Demirel, 2012; 373 Veugelers, 2012) EIs have three main forms (process, product, organ- 374 isational) and are driven by four main underlying factors ${ }^{6}$ : market, 375 technology, regulation and firm specific factors. ${ }^{7}$ We do extend the 376 set of drivers by including the role of unions involvement as part 377 of firm's specific factors that also represents a link to the territory 378 and community, which is overlooked in both management and eco- 379 nomic literatures as far as we know (Dangelico and Pontrandolfo, 380 2015; Dangelico, 2015a,b; Horbach et al., 2012; Murillo-Luna et al., 381 2008), although several works sprang out in the last years about the 382 role of external and internal (to the firm) factors that influence the 383 propensity to introduce environmental innovations: from customers, 384 intended both as final customers and customers in a supply-chain

\footnotetext{
5 It is interesting to note the specific approach taken by Dangelico and Pontrandolfo (2010), who define green products on the basis of the 'impact' on the environment namely less negative, null, or positive. This paper is nevertheless not concerned with impact analysis.

6 For an updated and comprehensive discussion on various definitions and measurement issues for applied research we refer to the new works by Barbieri et al. (forthcoming) and Mazzanti et al. (2016).

7 There are also works that look at the stimulating role of interactions with actors such as universities, public bodies, other firms (Cainelli et al., 2012), or business and non business actors, which include NGOs (Dangelico and Pontrandolfo, 2015).
} 4 5 366 67 9 0 1 3 4 67 87 78 380 381 383 384 385 
Table 2

Distribution of Els between unionised and non-unionised firms.

\begin{tabular}{|c|c|c|c|c|}
\hline & \multicolumn{3}{|c|}{ Unionised } & \multirow{4}{*}{$\begin{array}{l}\text { Test* for differences in proportions } \\
\text { Two groups: Non-unionised vs Unionised } \\
\text { Variable of interest: EI = Yes }\end{array}$} \\
\hline & No & Yes & Total & \\
\hline & $\%$ & $\%$ & $\%$ & \\
\hline & $\%$ & $\%$ & $\%$ & \\
\hline \multicolumn{5}{|c|}{ ENVINNO } \\
\hline No & 83.7 & 78.6 & 80.0 & $H_{a}^{1} p$-value: 0.09 \\
\hline Yes & 16.3 & 21.4 & 20.0 & $H_{a}^{2} p$-value: 0.18 \\
\hline Total & 100.0 & 100.0 & 100.0 & $H_{a}^{3} p$-value: 0.91 \\
\hline \multicolumn{5}{|c|}{ ENERGY } \\
\hline No & 90.2 & 83.3 & 85.2 & $H_{a}^{1} p$-value: 0.02 \\
\hline Yes & 9.8 & 16.7 & 14.8 & $H_{a}^{2} p$-value: 0.04 \\
\hline Total & 100.0 & 100.0 & 100.0 & $H_{a}^{3} p$-value: 0.97 \\
\hline \multicolumn{5}{|l|}{$\mathrm{CO}_{2}$} \\
\hline No & 92.2 & 87.1 & 88.5 & $H_{a}^{1} p$-value: 0.05 \\
\hline Yes & 7.8 & 12.9 & 11.5 & $H_{a}^{2} p$-value: 0.09 \\
\hline Total & 100.0 & 100.0 & 100.0 & $H_{a}^{3} p$-value: 0.95 \\
\hline \multicolumn{5}{|c|}{ EMISSIONS } \\
\hline No & 89.5 & 84.6 & 85.9 & $H_{a}^{1} p$-value: 0.06 \\
\hline Yes & 10.5 & 15.4 & 14.1 & $H_{a}^{2} p$-value: 0.13 \\
\hline Total & 100.0 & 100.0 & 100.0 & $H_{a}^{3} p$-value: 0.93 \\
\hline \multicolumn{5}{|c|}{ EMASISO } \\
\hline No & 92.8 & 82.8 & 85.6 & $H_{a}^{1} p$-value: 0.00 \\
\hline Yes & 7.2 & 17.2 & 14.4 & $H_{a}^{2} p$-value: 0.00 \\
\hline Total & 100.0 & 100.0 & 100.0 & $H_{a}^{3} p$-value: 0.99 \\
\hline
\end{tabular}

$H_{a}^{i}$ where $i=1,2,3$ are the alternative hypotheses. 1 and 3 one-sided; 2 two-sided. $\mathrm{HO}$ is not accepted when the $p$-value is less than 0.05 .

H0: Proportion of innovators non-unionised $=$ Proportion of innovators unionised. $H_{a}^{1}$ : Proportion of innovators non-unionised < Proportion of innovators unionised. $H_{a}^{2}$ : Proportion of innovators non-unionised $\neq$ Proportion of innovators unionised. $\mathrm{H}_{a}^{3}$ : Proportion of innovators non-unionised > Proportion of innovators unionised. * Z test with $95 \%$ confidence interval. H0 is the null hypothesis;

system (Qi et al., 2013; Simpson et al., 2007) to NGOs (Berrone et al., 2013), passing from the stringency of environmental policies (Frondel et al., 2008), for external factors; from the role of green supply chain integration on the green product and process innovation $(\mathrm{Wu}, 2013)$ to the importance of managerial concern as pointed out by Qi et al. (2010), for internal factors. Hence, the first research question concerns the impact that unions may have on Els, which according to the theoretical framework presented in Section 2, can be either positive or negative:

\section{R1 Is unionisation positively or negatively related to Els?}

The definition of the subsequent research question derives from the industrial relations literature, which recognises the indirect employees involvement ${ }^{8}$, through union representatives, (Martin, 1994; Nielsen and Lundvall, 2003) as a factor triggering a firm's propensity to innovate. The question also derives from the conceptual framework depicted in Carrillo-Hermosilla et al. (2010), which recognises the firms' governance structure as a critical dimension of EIs. The authors affirm that "successful eco-innovations are highly dependent on the participation of different stakeholders in their development/uptake" (Carrillo-Hermosilla et al., 2010, p.1082). Indeed, as pointed out by Murillo-Luna et al. (2008), the stakeholder

\footnotetext{
8 We do not focus here on the direct involvement of employees, since our focus is on the role of unions. However, there is an interesting article by Lanfranchi and Pekovic (2014) which points out the relation between the adoption of environmental standards and the wellbeing and perception of usefulness of 'green employees'. The authors also show that the adoption of environmental standards may indirectly influence the employees involvement.
}

pressures impact on environmental strategies and although they 49 do not encompass unions among the analysed agents, they iden- 499 tify the disclosure of environmental information as a key issue. 500 They emphasise 'stakeholder pressures' on management as the main 501 operational factor behind enhanced environmental performance. We 502 argue that the role of unions as 'stakeholders' is not only operat- 503 ing through 'pressures'. Being the unions involvement varied across 504 institutional settings, it may act as (conservative/progressive) exter- 505 nal pressure, or internal (conservative/progressive) lever of organisa- 506 tional change. In fact, unions can be considered as mixed stakehold- 507 ers in terms of objectives. Following (Simpson et al., 2007, p.31) that 508 state "the organisation 's choice of environmental strategy has more 509 to do with the needs of the organisation 's financial stakeholders", 510 we can argue that unions may be included among both 'financial' and 511 'non-financial' stakeholders, with a strong role of the private bene- 512 fit side. Indeed, the new issue is that even from the point of view 513 of unions the environment is an economic factor. This is an unro- 514 mantic but concrete view that may reconcile through innovation and 515 profits the usual employment/wage aim with environmental objec- 516 tives. The citation from Egri and Pinfeld (1996, p.472) in Simpson et 517 al. (2007) is also relevant: " from the perspective of organisational 518 theory, environmental degradation becomes relevant only when the 519 performance of a focal organisation and the welfare of organisational 520 participants are affected by such concerns". Radical changes derive from organisations that comprehensively perceive and adopt strate- 522 gies to reconcile by innovating the environment with wages, profits 523 and employment. The radicalness of the challenge may require the 524 action and competencies of both unions and management actors. $\quad 525$

We consider unions as important elements of the internal 526 governance structure and, as social actors, interested in the social 527 
Table 3

EIs variables.

\begin{tabular}{ll}
\hline Variable & Construction \\
\hline $\begin{array}{l}\text { Els } \\
\text { Environmental innovation (ENVINNO) }\end{array}$ & $\begin{array}{l}\text { Dummy variable: } 1 \text { if the firm introduced an environmental innovation, } 0 \\
\text { otherwise } \\
\text { Dummy variable: } 1 \text { if innovations intended to reduce use of materials } \\
\text { and/or energy per output unit (included recycling) have been adopted, } 0 \\
\text { otherwise } \\
\text { Energy/Material reduction per unit of product (ENERGY) } \\
\mathrm{CO}_{2} \text { reduction }\left(\mathbf{C O}_{2}\right)\end{array}$ \\
$\begin{array}{l}\text { Dumm variable: } 1 \text { if innovations intended to reduce } \mathrm{CO}_{2} \text { emissions have } \\
\text { been adopted, } 0 \text { otherwise } \\
\text { Dummy variable: } 1 \text { if innovations intended to reduce emissions affecting } \\
\text { soil, water and air have been adopted, } 0 \text { otherwise } \\
\text { Adoption of procedures such as EMAS and ISO14001 (EMASISO) } \\
\text { performance have been adopted, } 0 \text { otherwise }\end{array}$ \\
\hline
\end{tabular}

benefits provided by EIs ${ }^{9}$. The role of unions and workers involvement in firms decisions enables innovation through the 'organisational culture' factor, where firms'/unions leadership, autonomy of decision making, motivations, and organisational climates are idiosyncratic elements that may promote innovation and change (Crossan and Apaydin, 2010). The relationship between unions and management is relevant to shape innovation cultures (mission, goals, strategy, organisational learning and knowledge management). Hence, cooperative industrial relations, which translates at firm level into participative practices and unions involvement, may also help in overcoming a potential under-investment issue in EIs by the firms (Popp, 2010; Rennings and Rammer, 2009). Firms are private actors that may tend to overlook the social benefits of EIs, which can be considered as impure public goods (Corradini et al., 2014; Barrett, 2006) given the social benefits they entails. If firms do not internalise in their objective function the social benefits generated by EIs, then they could under-invest in EIs with respect to what could be a social optimum level of investment. Firm level unions, as actors representing workers interests and more widely, also the territory/community interests in which they are embedded as the workers they represent, may act as an element that enhance the firm propensity to introduce EIs when industrial relations are participative and the management is receptive to unions voice.

Collaboration and cooperation among stakeholders is a crucial element of the governance dimension, and consequently, union involvement and participation in decision making on innovative strategies becomes a crucial element for the Els development/ uptake. The second research question is thus:

R2 Is union involvement, as part of the governance dimension of the firm, positively related to the adoption of EIs?

In answering these questions, we are able to verify the association between the degree of union involvement and the adoption of various types of EIs ${ }^{10}$.

\subsection{Data and Empirical Strategy}

To answer our research questions, we base our analysis on microlevel data from a unique dataset concerning a sample of 555 Italian manufacturing firms with at least 20 employees located in the Emilia-Romagna region (a NUTS 2 level of analysis), which ranks 4th

\footnotetext{
9 The unstructured interviews to unions members as illustrated in the CECILIA2050 report (http://www.cecilia2050.eu, Inducing Greenhouse Gases Abating Innovations Through Policy Packages. Ex Post Assessments from EU Sectors) show the importance of the environmental issues for unions.

10 In addition, we can also indirectly test whether the limited firm-level debate on and union involvement in green issues, as emerged by the unstructured interviews we conducted (here not included for scope constraints), have consequences for EI development/uptake.
}

in regional GDP in Italy and as the 3rd-largest regional industrial value added and accounts for approximately of the $7 \%$ of the Italian population. The information collected refers to the pre-crisis period (2006-2008). The random sample is stratified by size, geographic location (province level, NUTS 3 ) and sector. It is well representative of the population, exhibiting only minor distortions (see Table B1).

A multidimensional questionnaire ${ }^{11}$ that investigates several dimensions of firm innovation activity, including environmental innovation, and provides information on union involvement in the decision-making process along six dimensions of innovation activity (see Table 1) was used to construct the dataset in order to carry out the present analysis.

The original survey we used to collect our data was carried on by a professional contractor (SWG, http://www.swg.it/en) through CATI (Computer Assisted Telephone Interview) interviews. The respondents were managers/owners involved in the definition of innovation strategies and deployment of adopted innovations. When they lack of some information concerning specific section of the questionnaire (e.g. section on human resource training) they were requested to refer to other managers possessing those information in order to minimise the number of missing values.

As we can see, the presence of union representatives at the firm level (see Table B2 in Appendix B) implies some form of involvement in the decision process: a substantial minority of firms do not involve unions at all (No involvement). Moreover only a small fraction of firms, fewer than the number of firms that do not involve unions, bargains with unions during the decision process regarding changes affecting one of the six innovation dimensions. The large majority of firms inform the union representatives of the changes they plan to introduce, and a non-negligible fraction of firms consult the unions.

Firms appear aware of the importance of union involvement as tool that can facilitate and smooth the adoption of innovations.

Moreover, as Table 2 shows, the unionised firms are more inclined to introduce some type of EIs: the alternative hypothesis that the proportion of firms introducing some type of Els is larger for unionised firms than for non-unionised $\left(H_{a}^{1}\right)$ is almost always not-rejected.

We classify EIs into four types ${ }^{12}$ : Els introduced to reduce the consumption of energy (ENERGY), to reduce the emissions of $\mathrm{CO}_{2}$ $\left(\mathrm{CO}_{2}\right)$, to reduce the emissions of other air, soil and water pollutants (EMISSION) and to change the process and obtain green certificates (EMASISO). A general variable is also used to capture whether a firm introduced at least one of the EIs mentioned above (see Table 3 ).

\footnotetext{
11 Although the questionnaire is an original work, which provides unique information, we referred mainly to the Community Innovation Survey (http://ec.europa.eu/ eurostat/web/microdata/community-innovation-survey) as a source for the formulation of some questions (e.g. questions on the adoption of EIs).

12 For a fine-grained ex-post based definition of green product innovations we refer the interested reader to Dangelico and Pontrandolfo (2010) who propose a Green Option Matrix to identify green product and practices.
} 
Table 4

Covariates.

\begin{tabular}{|c|c|}
\hline Variable & Construction \\
\hline \multicolumn{2}{|l|}{ Controls } \\
\hline Size dummies & Size dummy by employee: 1 if the number of employees is higher than 250,0 otherwise \\
\hline Sector dummies & $\begin{array}{l}\text { Sector dummies based on two-digit NaceRev.1 classification (Food, Machinery, } \\
\text { NonMetallicMineralProd, CokeChemical, WoodRubberPlasticOther, Textile, Shoes, } \\
\text { PaperPrinting, Metallurgy). Sectors were grouped according to the RAMEA grouping. }\end{array}$ \\
\hline Geo & $\begin{array}{l}\text { Geographical location of the firm. Dummy: } 1 \text { if the firm belongs to one of the } 4 \text { provinces } \\
\text { located in the industrialised centre of the Emila-Romagna region (Bologna, Modena, Reggio } \\
\text { Emilia, Parma) }\end{array}$ \\
\hline EI_DIFF & Share of environmental innovating firms geographically clustered in the same municipality \\
\hline ICT & Composite index capturing the presence of complex ICT adopted within the firm \\
\hline TrainCov & Percentage of permanent workers covered by training programmes \\
\hline OrgProd & Composite organisational index capturing changes in production organisation \\
\hline OrgLab & Composite organisational index capturing changes in labour organisation \\
\hline \multicolumn{2}{|l|}{ Demand Pull } \\
\hline Export & Percentage of turnover made on international markets \\
\hline MarketDem & Sector-based average of firms declaring to have adopted Els because of market demand \\
\hline \multicolumn{2}{|l|}{ Technology Push } \\
\hline RD_IN & Dummy: 1 if the firm conducted intramural R\&D, 0 otherwise \\
\hline RD_EX & Dummy: 1 if the firm conducted extramural R\&D, 0 otherwise \\
\hline TechInvest & $\begin{array}{l}\text { Dummy: } 1 \text { if the firm invested in the acquisition of new technologies, machines or software, } 0 \\
\text { otherwise }\end{array}$ \\
\hline \multicolumn{2}{|c|}{ Environmental Regulation } \\
\hline Regul & $\begin{array}{l}\text { Sector-based average of firms reporting to have adopted EIs because of environmental } \\
\text { regulation }\end{array}$ \\
\hline \multicolumn{2}{|l|}{ Unionisation } \\
\hline Union & Dummy: 1 if the firm is unionised, 0 otherwise \\
\hline \multicolumn{2}{|l|}{ Unions Involvement } \\
\hline UnionInv & $\begin{array}{l}\text { Index capturing the degree of involvement of the union representatives in relation to } \\
\text { innovation strategies. The higher the index, the higher the degree of unions involvement. }\end{array}$ \\
\hline UnionInfo & Dummy: 1 if unions are informed of green innovation decisions, 0 otherwise \\
\hline UnionCons & Dummy: 1 if unions are consulted on green innovation decisions, 0 otherwise \\
\hline UnionBarg & Dummy: 1 if unions and management bargain over green innovation decisions, 0 otherwise \\
\hline
\end{tabular}

Regarding the explanatory variables for the decision to introduce EIs, we use information that refers to the technology push, demand pull and regulatory determinants of Els (see for example Borghesi et al., 2015b; Cainelli et al., 2012; Del Río et al., 2015). These types of determinants are crucial for EIs, as for other innovations, and hence they are relevant variables for our analysis, but here they are used as background factors, while the main focus is on the role of unionisation and union involvement, which are elements additional to the main determinants of Els, as they are also relevant for the introduction of other innovations. Table 4 reports the description of the explanatory variables used in the analysis.

The first step of the analysis is to estimate the following 'environmental innovation function' for the entire sample of 555 unionised and non-unionised firms:

$\operatorname{Prob}(Y=1 \mid \boldsymbol{x})=\Phi\left(\boldsymbol{x}^{\prime} \beta\right)$

where $\Phi$ is the standard normal distribution; $\boldsymbol{x}$ includes the Controls, INNO variables and a dummy variable capturing the presence of unions at the firm level (Union_d);

The second step of the analysis is to estimate the following 'environmental innovation function' for the 402 unionised firms, accounting for the participatory climate at the firm level:

$\operatorname{Prob}(Y=1 \mid \boldsymbol{z})=\Phi\left(\boldsymbol{z}^{\prime} \beta\right)$

where $\Phi$ is the standard normal distribution; $\boldsymbol{z}$ includes the same variables as in the vector $\boldsymbol{x}$ plus past firm performance but excludes the Union_d dummy, which is instead substituted for variables representing union representatives' involvement that capture, first, the union representatives' involvement (UNIONINV) in all strategic spheres listed in the questionnaire (organisation, technology, ICT, training, EIs, internationalisation) and, second, through specific involvement dummies for the EIs (UnionInfoEI, UnionConsEI, UnionBargEI) that capture the presence of information, consultation or bargaining on the strategic decision to implement EIs ${ }^{13}$. As far as UNIONINV index is concerned it is constructed as follows: at first, three indexes of involvement are constructed, each one referred to information, consultation and bargaining respectively (e.g. Information $=$ number of innovation strategies concerning which the management decides to inform union representatives divided by the total number of innovation strategies considered in the question (6); see Q4 in Appendix A). Subsequently the composite UNIONINV

\footnotetext{
13 The distinction of unions involvement in this three dimensions is motivated by the fact that such dimensions discriminate in an informative way the modalities according to which union representatives and managers may interact in Italian firms. Since we are here interested in the dialogue between managers and union representatives on firm strategic decision, beside the case of absence of interaction when the index takes the value 0 , it is possible that managers simply inform union representatives on their innovation strategies (ex-post interaction which takes place after the managerial decision), consult union representatives (ex-ante interaction, but the decision is left to managers) and bargain with union representatives the way through which pursue innovation strategies (ex-ante cooperative form of interaction between managers and unions). These three dimensions exhaustively encompass the way unions and managers can interact on complex issues such as innovation strategies at firm level in Italy (see Antonioli et al., 2011 and Antonioli et al., 2009 for the use of a similar index in previous works).
} 
Table 5

Probit results with ENVINNO as dependent variable.

\begin{tabular}{|c|c|c|c|c|c|}
\hline & (1) & $(2)$ & (3) & $(4)$ & (5) \\
\hline \multicolumn{6}{|l|}{ Controls } \\
\hline Size $(d)$ & Yes & Yes & Yes & Yes & Yes \\
\hline Sector (d) & Yes & Yes & Yes & Yes & Yes \\
\hline $\mathrm{Geo}(\mathrm{d})$ & Yes & Yes & Yes & Yes & Yes \\
\hline \multirow[t]{2}{*}{ EI_DIFF } & $0.707^{* * *}$ & $0.708^{* * *}$ & $0.762^{* * *}$ & $0.766^{* * *}$ & $0.764^{* * *}$ \\
\hline & $(0.062)$ & $(0.062)$ & $(0.072)$ & $(0.072)$ & $(0.072)$ \\
\hline \multirow[t]{2}{*}{ OrgProd } & $0.136^{* * * *}$ & $0.135^{* * * *}$ & $0.132^{* * *}$ & $0.127^{* *}$ & $0.137^{* * *}$ \\
\hline & $(0.045)$ & $(0.045)$ & $(0.054)$ & $(0.054)$ & $(0.053)$ \\
\hline \multirow[t]{2}{*}{ OrgLab } & 0.051 & 0.054 & 0.092 & 0.085 & 0.075 \\
\hline & $(0.071)$ & $(0.071)$ & $(0.081)$ & $(0.081)$ & $(0.079)$ \\
\hline \multirow[t]{2}{*}{ TrainCov } & $0.121^{\text {**** }}$ & $0.120^{* * * *}$ & $0.110^{* * * *}$ & $0.109^{* *}$ & $0.119^{* * *}$ \\
\hline & $(0.035)$ & $(0.035)$ & $(0.043)$ & $(0.043)$ & $(0.042)$ \\
\hline \multicolumn{6}{|l|}{ Demand Pull } \\
\hline \multirow[t]{2}{*}{ Export } & $0.080^{*}$ & $0.082^{*}$ & $0.130^{* *}$ & $0.131^{* * *}$ & $0.123^{* *}$ \\
\hline & $(0.044)$ & $(0.044)$ & $(0.053)$ & $(0.053)$ & $(0.051)$ \\
\hline \multirow[t]{2}{*}{ MarketDem } & $5.331^{* * * *}$ & $5.395^{* * *}$ & $5.475^{* * * *}$ & $5.464^{* * *}$ & $5.201^{* * *}$ \\
\hline & $(1.017)$ & $(1.021)$ & $(1.186)$ & $(1.220)$ & $(1.171)$ \\
\hline \multicolumn{6}{|l|}{ Technology Push } \\
\hline \multirow[t]{2}{*}{ RD_IN (d) } & -0.015 & -0.015 & -0.052 & -0.054 & -0.059 \\
\hline & $(0.034)$ & $(0.034)$ & $(0.040)$ & $(0.040)$ & $(0.040)$ \\
\hline \multirow[t]{2}{*}{ RD_EX (d) } & -0.002 & -0.002 & 0.026 & 0.025 & 0.027 \\
\hline & $(0.028)$ & $(0.028)$ & $(0.032)$ & $(0.032)$ & $(0.031)$ \\
\hline \multirow[t]{2}{*}{ TechInvest (d) } & 0.065 & 0.065 & $0.126^{* *}$ & $0.128^{* * *}$ & $0.115^{* *}$ \\
\hline & $(0.046)$ & $(0.046)$ & $(0.057)$ & $(0.057)$ & $(0.059)$ \\
\hline \multicolumn{6}{|c|}{ Environmental Regulation } \\
\hline \multirow[t]{2}{*}{ Regul } & 0.330 & 0.313 & -0.008 & -0.015 & 0.045 \\
\hline & $(0.453)$ & $(0.447)$ & $(0.537)$ & $(0.546)$ & $(0.508)$ \\
\hline \multicolumn{6}{|l|}{ Unionisation } \\
\hline Union & & 0 & & & \\
\hline \multicolumn{6}{|c|}{ Union Involvement } \\
\hline \multirow[t]{2}{*}{ UnionInv } & & & & 0.047 & \\
\hline & & & & $(0.054)$ & \\
\hline \multicolumn{2}{|l|}{ UnionInfo (d) } & & & & $0.126^{* * *}$ \\
\hline & & & & & $(0.045)$ \\
\hline \multicolumn{2}{|l|}{ UnionCons (d) } & & & & 0.075 \\
\hline & & & & & $(0.056)$ \\
\hline \multirow{2}{*}{\multicolumn{2}{|c|}{ UnionBarg (d) }} & & & & $0.119^{* * *}$ \\
\hline & & & & & $(0.059)$ \\
\hline$N$ & 555 & 555 & 402 & 402 & 402 \\
\hline Pseudo_R ${ }^{2}$ & 0.430 & 0.430 & 0.452 & 0.453 & 0.471 \\
\hline \multirow[t]{5}{*}{$\mathrm{Chi}^{2}$} & $1060.50(17)$ & $938.60(18)$ & $988.28(17)$ & $916.18(18)$ & $593.91(20)$ \\
\hline & & meshow good & $\mathrm{Chi}^{2}(\mathrm{df})$ & & \\
\hline & $9.52(8)$ & $10.40(8)$ & $3.23(8)$ & $1.75(8)$ & $5.52(8)$ \\
\hline & & Correctly & & & \\
\hline & $87.03 \%$ & $86.31 \%$ & $86.82 \%$ & $87.81 \%$ & $86.82 \%$ \\
\hline
\end{tabular}

Marginal effects; Standard errors are in parentheses.

(d) for discrete change of dummy variable from 0 to 1 .

*** $p<0.01$

** $p<0.05$.

$* p<0.10$.

index is constructed as the mean of the three indexes of involvement. So that, the higher the UNIONINV index the higher the degree of unions involvement in the decision making concerning innovation strategies. As reported in Appendix A, the question related to the union representatives' involvement (Q4) allows us to construct further different types of variables that capture union participation in the decision-making process. In particular, in order to isolate the importance of union involvement in spurring EI adoption, we consider how management and unions interact on green strategies ${ }^{14}$.

\footnotetext{
14 We also used union involvement variables for other innovation strategies to support the idea that involvement, whether in EIs or other innovation strategies, is a key factor. The main results reported in the next section are confirmed. The results are available from the authors upon request.
}

The three binary variables introduced above (UnionInfoEI, Union- 910 ConsEI, UnionBargEI) have a further characteristic that allows us to 911 use them jointly in a single specification:the presence of a modal- 912 ity of union involvement excludes the other two (see Table B3 in 913 Appendix B).

In addition, as we are aware of potential endogeneity problems 915 in our specification, we also attempted to estimate models with 916 Instrumental Variables (IVs). We searched for suitable instruments 917 among social aspects potentially related to unionisation and union 918 involvement. Because the major union organisation in Italy (CGIL) 919 is a left-wing union and represents the largest share of unionised 920 workers, we opted for the 'share of left-wing voters in the 2006 gen- 921 eral election by municipality in Emilia-Romagna' as instrument for 922 both unionisation and union participation in the decision-making 923 process within the firm. The instrument constructed was not robust: 924 
Table 6

Probit results with ENERGY as dependent variable.

\begin{tabular}{|c|c|c|c|c|c|}
\hline & (1) & $(2)$ & (3) & (4) & (5) \\
\hline \multicolumn{6}{|l|}{ Controls } \\
\hline Size $(d)$ & Yes & Yes & Yes & Yes & Yes \\
\hline Sector (d) & Yes & Yes & Yes & Yes & Yes \\
\hline Geo $(d)$ & Yes & Yes & Yes & Yes & Yes \\
\hline \multirow[t]{2}{*}{ EI_DIFF } & $0.435^{\text {**** }}$ & $0.432^{* * *}$ & $0.495^{* * *}$ & $0.495^{\text {**** }}$ & $0.491^{* * *}$ \\
\hline & $(0.045)$ & $(0.044)$ & $(0.057)$ & $(0.057)$ & $(0.055)$ \\
\hline \multirow[t]{2}{*}{ OrgProd } & $0.131^{* * *}$ & $0.133^{* * *}$ & $0.106^{* *}$ & $0.109^{* * *}$ & $0.112^{* *}$ \\
\hline & $(0.043)$ & $(0.043)$ & $(0.051)$ & $(0.052)$ & $(0.050)$ \\
\hline \multirow[t]{2}{*}{ OrgLab } & 0.065 & 0.059 & 0.089 & 0.092 & 0.087 \\
\hline & $(0.072)$ & $(0.072)$ & $(0.083)$ & $(0.083)$ & $(0.082)$ \\
\hline \multirow[t]{2}{*}{ TrainCov } & $0.099^{* * * *}$ & $0.102^{* * * *}$ & $0.120^{* * * *}$ & $0.121^{\text {**** }}$ & $0.127^{* * * *}$ \\
\hline & $(0.031)$ & $(0.031)$ & $(0.039)$ & $(0.039)$ & $(0.039)$ \\
\hline \multicolumn{6}{|l|}{ Demand Pull } \\
\hline \multirow[t]{2}{*}{ Export } & $0.071^{*}$ & $0.067^{*}$ & $0.081^{*}$ & $0.081^{*}$ & 0.065 \\
\hline & $(0.039)$ & $(0.040)$ & $(0.047)$ & $(0.047)$ & $(0.047)$ \\
\hline \multirow[t]{2}{*}{ MarketDem } & $5.030^{* * * *}$ & $4.918^{* * * *}$ & $5.615^{* * * *}$ & $5.655^{* * * *}$ & $5.318^{* * *}$ \\
\hline & $(0.856)$ & $(0.854)$ & $(1.051)$ & $(1.047)$ & $(0.976)$ \\
\hline \multicolumn{6}{|l|}{ Technology Push } \\
\hline \multirow[t]{2}{*}{ RD_IN (d) } & $0.072^{*}$ & $0.074^{*}$ & 0.061 & 0.061 & 0.079 \\
\hline & $(0.039)$ & $(0.039)$ & $(0.050)$ & $(0.050)$ & $(0.053)$ \\
\hline \multirow[t]{2}{*}{ RD_EX (d) } & 0.033 & 0.033 & $0.055^{*}$ & $0.056^{*}$ & $0.054^{*}$ \\
\hline & $(0.024)$ & $(0.024)$ & $(0.029)$ & $(0.029)$ & $(0.029)$ \\
\hline \multirow[t]{2}{*}{ TechInvest (d) } & 0.057 & 0.058 & 0.056 & 0.055 & 0.053 \\
\hline & $(0.047)$ & $(0.047)$ & $(0.054)$ & $(0.054)$ & $(0.053)$ \\
\hline \multicolumn{6}{|c|}{ Environmental Regulation } \\
\hline \multirow[t]{2}{*}{ Regul } & -0.114 & -0.081 & -0.257 & -0.260 & -0.206 \\
\hline & $(0.372)$ & $(0.376)$ & $(0.461)$ & $(0.457)$ & $(0.432)$ \\
\hline \multicolumn{6}{|l|}{ Unionisation } \\
\hline \multirow[t]{2}{*}{ Union } & & 0.025 & & & \\
\hline & & $(0.030)$ & & & \\
\hline \multicolumn{6}{|c|}{ Union Involvement } \\
\hline \multirow[t]{2}{*}{ UnionInv } & & & & -0.028 & \\
\hline & & & & $(0.058)$ & \\
\hline \multirow{2}{*}{\multicolumn{2}{|c|}{ UnionInfo (d) }} & & & & $0.085^{* *}$ \\
\hline & & & & & $(0.043)$ \\
\hline \multirow{2}{*}{\multicolumn{2}{|c|}{ UnionCons (d) }} & & & & 0.004 \\
\hline & & & & & $(0.059)$ \\
\hline \multirow[t]{2}{*}{ UnionBarg (d) } & & & & & 0.068 \\
\hline & & & & & $(0.061)$ \\
\hline$N$ & 555 & 555 & 402 & 402 & 402 \\
\hline Pseudo_R ${ }^{2}$ & 0.393 & 0.394 & 0.394 & 0.394 & 0.412 \\
\hline $\mathrm{Chi}^{2}$ & $844.77(17)$ & $1048.87(18)$ & $1065.89(17)$ & $1013.84(18)$ & $714.45(20)$ \\
\hline Hosmer-Lemes & & & & & \\
\hline & $7.10(8)$ & $9.32(8)$ & $10.40(8)$ & $6.77(8)$ & $10.09(8)$ \\
\hline Correctly class & & & & & \\
\hline & $88.29 \%$ & $88.11 \%$ & $87.06 \%$ & $87.31 \%$ & $86.82 \%$ \\
\hline
\end{tabular}

Marginal effects; Standard errors are in parentheses.

(d) for discrete change of dummy variable from 0 to 1 .

*** $p<0.01$.

** $p<0.05$

${ }^{*} p<0.10$.

it was too weak to be used in the analysis as a reliable instrument. We obtained the same result using a less-refined instrument: 'the electoral turnover in the general election of 2006 by municipality in Emilia-Romagna'.

\section{Results}

First, as we can see in Tables 5-9, several 'innovation-related factors' are linked to the probability of El adoption. First, sector relatedness matters: being a firm in a sector subject to the ETS (a polluting sector) increases the probability of adopting energy-saving EIs. This is always crucial for EIs, since environmental policies often have specific sector features; in addition, heavy manufacturing sectors are often subject to more stringent policies and may tend to innovate more. This is a crucial element for creating synergies between industrial/economic aims and environmental targets (e.g. the aforementioned EU industrial and environmental strategies). Second, the rate of diffusion of Els within the same municipality influence the probability of adoption for any type of El. The role of spatial agglomeration and spillovers has been substantially neglected in works on EIs determinants (see the following works for some examples concerning the role of spatial factors: Cainelli et al., 2012; Horbach, 2013; Corsatea, 2014). We here stress the importance of identifying the level of boundaries within which agglomeration economies operate. The results for the EI_DIFF variable suggest the presence of positive spillover effects of Els within municipality boundaries (Antonioli et al., forthcoming).

Concerning the organisational innovation variables, which are 1055 part of the High Performance Work Practices (HPWP), we note the 1056 
Table 7

Probit results with $\mathrm{CO}_{2}$ as dependent variable.

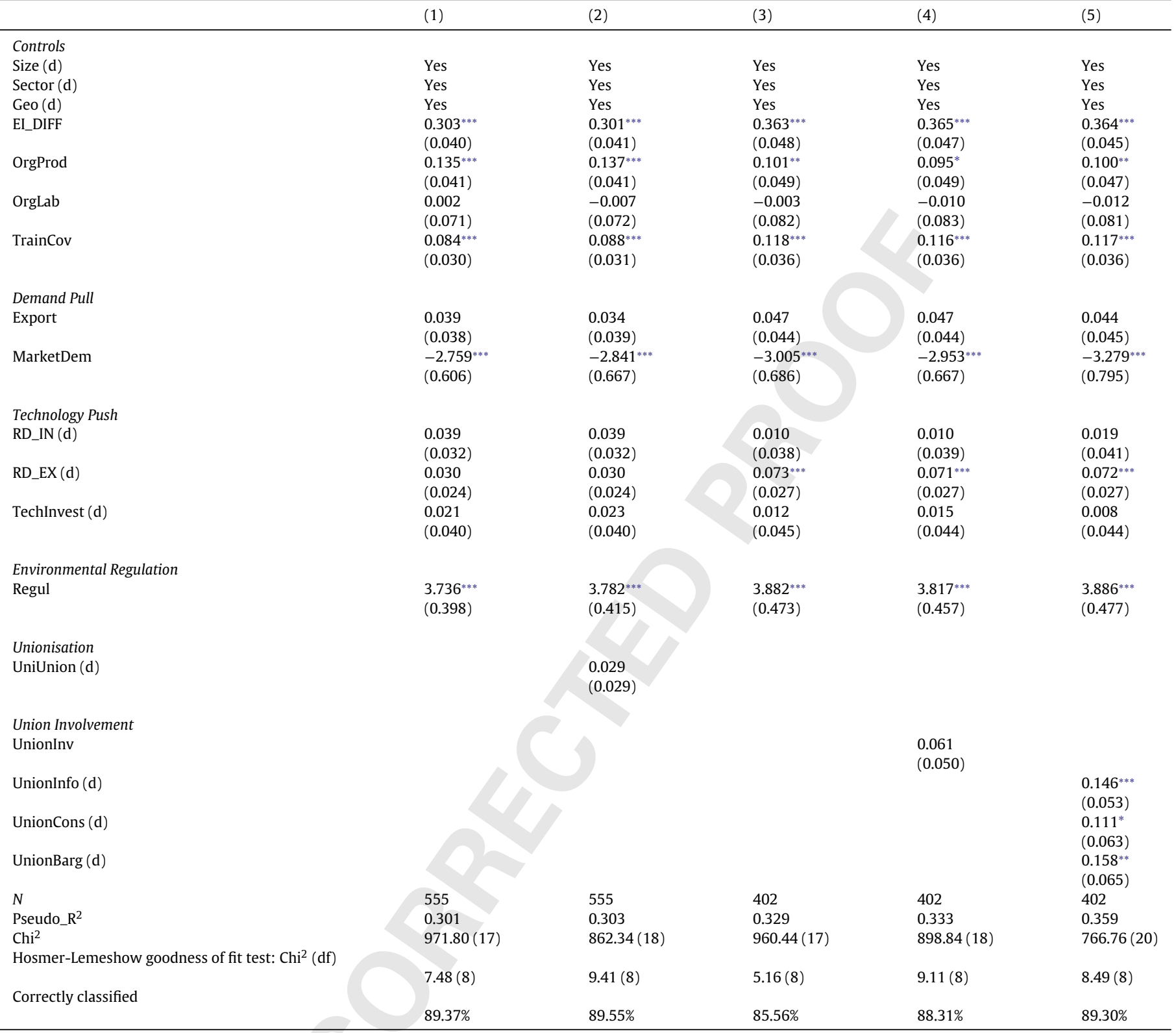

Marginal effects; Standard errors are in parentheses.

(d) for discrete change of dummy variable from 0 to 1 .

*** $p<0.01$.

** $p<0.05$

$* p<0.10$.

importance of two types of innovations as factors related to El adoption: changes in production organisation and the coverage of training programmes. These two types of innovations are complementary with respect to the EIs adoption propensity (Antonioli et al., 2013). In addition, HPWP imply strategies where the role of unions is relevant, especially for managing training programmes. However, the role of $R \& D$ should not be neglected. Indeed, some specific Els are related to intramural or extramural R\&D $\mathrm{D}^{15}$ Even if other studies tend to under emphasise the role of R\&D (Cainelli et al., 2012), and even in this

\footnotetext{
15 Specifically, energy-saving and $\mathrm{CO}_{2}$-reducing innovations are related to both intramural and extramural R\&D (Tables 6 and 7), while the organisational changes introduced to acquire green certificates are primarily related to technological invest-
} ments (Table 9). analysis R\&D is not the key leading factor, we note that especially for more complex innovation realms (e.g. $\mathrm{CO}_{2}$ ), external sources of knowledge are pretty relevant. All in all regarding the link with the broad 'innovation' realm, EIs show integration with other innovation investments both in the input and output sides.

Turning to the main variables of interest to test our research hypotheses, we note that unionisation does not per se influence the probability of environmental innovation, as specifications (1) and (2) show (Tables 5-9). The analysis for the full sample of firms, conducted to test the role of simple unionisation on the propensity to introduce environmental innovation, leads us to reject $R 1$ : unionisation does not influence the probability of environmental innovation adoption. This result is not unexpected, since the empirical literature has provided ambiguous evidence on the role of unions on innovation, as reported in Section 2. Unionisation is anyhow a rough 
Table 8

Probit results with EMISSIONS as dependent variable.

\begin{tabular}{|c|c|c|c|c|c|}
\hline & (1) & (2) & (3) & $(4)$ & (5) \\
\hline \multicolumn{6}{|l|}{ Controls } \\
\hline Size $(d)$ & Yes & Yes & Yes & Yes & Yes \\
\hline Sector (d) & Yes & Yes & Yes & Yes & Yes \\
\hline Geo $(d)$ & Yes & Yes & Yes & Yes & Yes \\
\hline \multirow[t]{2}{*}{ EI_DIFF } & $0.376^{* * * *}$ & $0.375^{* * * *}$ & $0.448^{* * * *}$ & $0.450^{* * * *}$ & $0.443^{* * * *}$ \\
\hline & $(0.045)$ & $(0.045)$ & $(0.055)$ & $(0.042)$ & $(0.053)$ \\
\hline \multirow[t]{2}{*}{ OrgProd } & $0.091^{* *}$ & $0.091^{* * *}$ & 0.076 & 0.069 & 0.074 \\
\hline & $(0.043)$ & $(0.044)$ & $(0.052)$ & $(0.052)$ & $(0.051)$ \\
\hline \multirow[t]{2}{*}{ OrgLab } & 0.041 & 0.038 & 0.077 & 0.068 & 0.063 \\
\hline & $(0.075)$ & $(0.076)$ & $(0.087)$ & $(0.088)$ & $(0.086)$ \\
\hline \multirow[t]{2}{*}{ TrainCov } & $0.093^{* * *}$ & $0.095^{* * * *}$ & $0.111^{* * * *}$ & $0.110^{* * * *}$ & $0.115^{* * * *}$ \\
\hline & $(0.034)$ & $(0.034)$ & $(0.039)$ & $(0.039)$ & $(0.039)$ \\
\hline \multicolumn{6}{|l|}{ Demand Pull } \\
\hline \multirow[t]{2}{*}{ Export } & 0.053 & 0.050 & $0.095^{*}$ & $0.095^{*}$ & $0.099^{*}$ \\
\hline & $(0.043)$ & $(0.043)$ & $(0.051)$ & $(0.050)$ & $(0.051)$ \\
\hline \multirow[t]{2}{*}{ MarketDem } & $-3.462^{* * *}$ & $-3.518^{* * *}$ & $-3.885^{* * *}$ & $-3.759^{* * *}$ & $-3.903^{* * *}$ \\
\hline & $(0.619)$ & $(0.631)$ & $(0.810)$ & $(0.661)$ & $(0.837)$ \\
\hline \multicolumn{6}{|l|}{ Technology Push } \\
\hline \multirow[t]{2}{*}{ RD_IN (d) } & 0.022 & 0.022 & 0.031 & 0.030 & 0.027 \\
\hline & $(0.036)$ & $(0.036)$ & $(0.051)$ & $(0.051)$ & $(0.053)$ \\
\hline \multirow[t]{2}{*}{ RD_EX (d) } & -0.001 & -0.001 & 0.047 & 0.045 & $0.049^{*}$ \\
\hline & $(0.027)$ & $(0.027)$ & $(0.030)$ & $(0.029)$ & $(0.029)$ \\
\hline \multirow[t]{2}{*}{ TechInvest (d) } & 0.020 & 0.020 & 0.065 & 0.067 & 0.060 \\
\hline & $(0.043)$ & $(0.043)$ & $(0.057)$ & $(0.056)$ & $(0.057)$ \\
\hline \multicolumn{6}{|c|}{ Environmental Regulation } \\
\hline \multirow[t]{2}{*}{ Regul } & $4.515^{* * * *}$ & $4.541^{\text {******* }}$ & $4.739^{* * * *}$ & $4.657^{* * * *}$ & $4.706^{* * * *}$ \\
\hline & $(0.444)$ & $(0.436)$ & $(0.582)$ & $(0.396)$ & $(0.558)$ \\
\hline \multicolumn{6}{|l|}{ Unionisation } \\
\hline \multirow[t]{2}{*}{ Union } & & 0.013 & & & \\
\hline & & $(0.032)$ & & & \\
\hline \multicolumn{6}{|c|}{ Union Involvement } \\
\hline \multirow[t]{2}{*}{ UnionInv } & & & & 0.063 & \\
\hline & & & & $(0.052)$ & \\
\hline \multicolumn{2}{|l|}{ UnionInfo (d) } & & & & $0.079^{*}$ \\
\hline & & & & & $(0.044)$ \\
\hline \multirow[t]{2}{*}{ UnionCons (d) } & & & & & $0.085^{*}$ \\
\hline & & & & & $(0.051)$ \\
\hline \multirow[t]{2}{*}{ UnionBarg (d) } & & & & & 0.089 \\
\hline & & & & & $(0.060)$ \\
\hline \multirow{6}{*}{$\begin{array}{l}N \\
\text { Pseudo_R } \\
\text { Chi }^{2} \\
\text { Hosmer-Lemesl }\end{array}$} & 555 & 555 & 402 & 402 & 402 \\
\hline & 0.277 & 0.278 & 0.341 & 0.344 & 0.350 \\
\hline & $1278.85(17)$ & $1267.24(18)$ & $1223.26(17)$ & $1441.05(18)$ & $1086.52(20)$ \\
\hline & 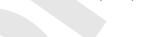 & & & & \\
\hline & $16.43(8)$ & $13.37(8)$ & $4.03(8)$ & $6.84(8)$ & $4.67(8)$ \\
\hline & & & & & \\
\hline & $87.21 \%$ & $87.39 \%$ & $87.81 \%$ & $87.81 \%$ & $87.81 \%$ \\
\hline
\end{tabular}

Marginal effects; Standard errors are in parentheses.

(d) for discrete change of dummy variable from 0 to 1 .

*** $p<0.01$.

** $p<0.05$.

$* p<0.10$.

proxy of the involvement and role of workers and their representatives within firm's decisions. In addition, the pretty high unionisation intensity in manufacturing firms in some industrial contexts need deeper investigations on the quality and type of union's role.

In order to put in evidence the moderating role of unions involvement we turn our attention on the unionised firms. The hypothesis we test is a positive linkage, for these kind of firms, between EIs and a participative work environment. Indeed, when we analyse the linkage between industrial relations and EI, for the sub-sample of unionised firms (specifications (3) to (5) in Tables 5-9) we note that specific types of involvement matter. 'Information' and 'bargaining' are related to EI, in the general EI regression (Table 5).

The general result Table 5 shows is original and interesting, but it hides differences in relation to the importance of union's involvement. The adoptions of more complex organisational and technological innovations (EMASISO, $\mathrm{CO}_{2}$ ) are the cases where both information 1306 and bargaining matter (Tables 7 and 9). In addition, we note that 1307 especially for tackling the complex $\mathrm{CO}_{2}$ abatement, the management 1308 and the unions are co-involved through bargaining. Redefining the 1309 organisation and restructuring the technological portfolio induces the 1310 management to involve the unions in the development of innovation 1311 strategies. Two models seem necessary and relevant within a general 1312 'need' of involving workers through unions: one where the manage- 1313 ment is more self sufficient but inform unions, the other where unions 1314 involvement is strong. When t he costs for EIs are higher, interme- 1315 diate solutions (e.g. unions consultation) do not provide sufficient 1316 benefits. Benefits given by unions involvement, even through interme- 1317 diate solutions such as consultation(only at $10 \%$ statistical significance 1318 though), seems higher - as expected - when mixed private/public 1319 issues are at stake (e.g. reducing a global public good such as $\mathrm{CO}_{2}$ ). ${ }_{1320}$ 
Table 9

Probit results with EMASISO as dependent variable.

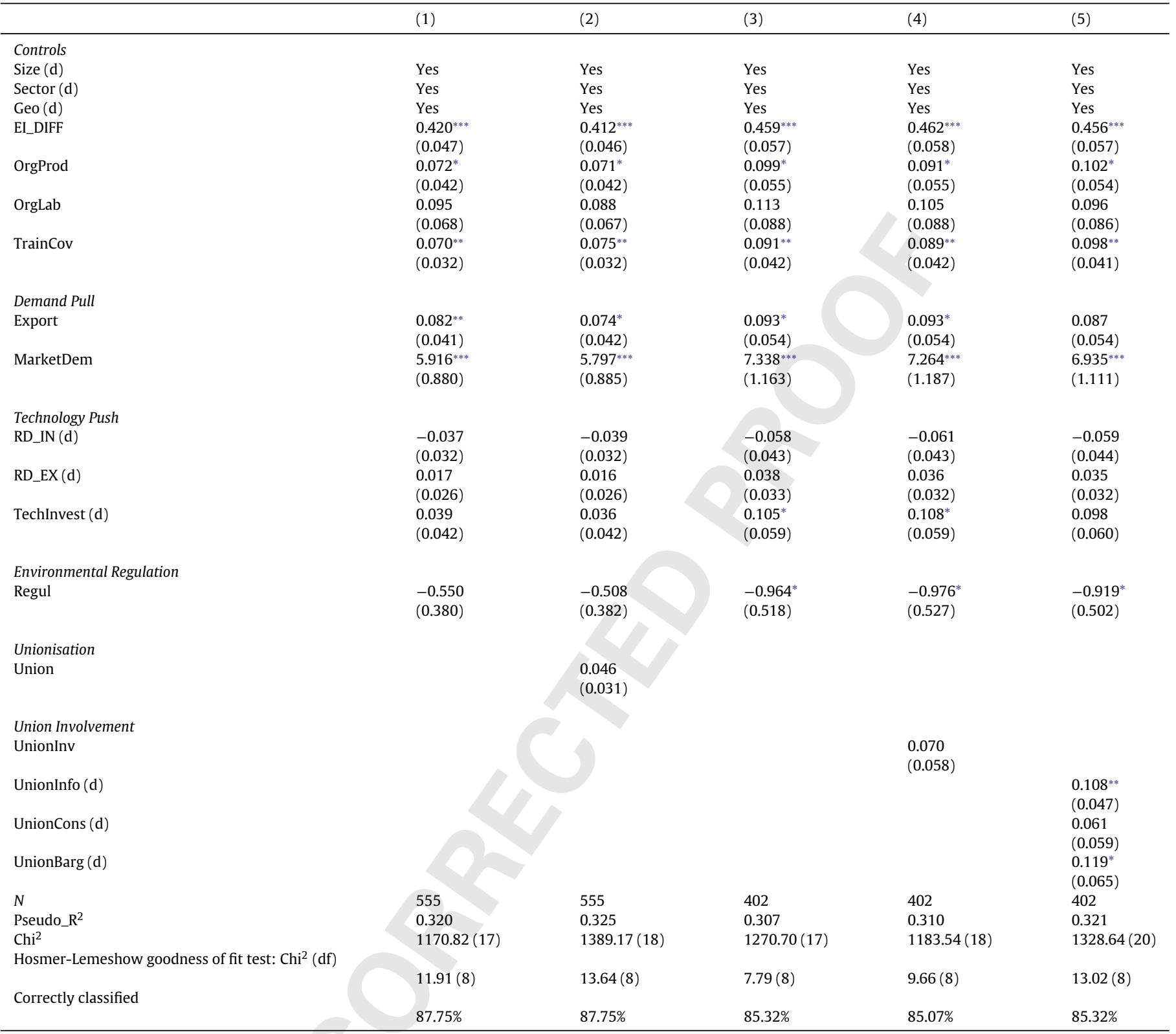

Marginal effects; Standard errors are in parentheses.

(d) for discrete change of dummy variable from 0 to 1 .

*** $p<0.01$.

** $p<0.05$

$* p<0.10$.

On the contrary, energy-saving innovations are related only to union information (Table 6): the higher the economic appropriability of Els adoption (win-win energy solutions), the lower the need to involve through bargain. The management is self sufficient.

Finally, the weakest role of unions-management interactions in terms of statistical significance (10\% significance level both for union information and bargaining) is found for emission reducing technologies, where simpler technological (e.g. end of pipe) solutions predominate (Table 8 ).

In relation to the second research question $(R 2)$, the evidence we find is not trivial. In fact, it seems that a non-linear relationship between union involvement and El emerges: a managerially driven approach to introducing EI (when unions are only informed of managerial intent) and an industrial-relations driven approach (when EIs are introduced through a process of bargaining between unions and management), which seem to co-exist in the analysed manu- ${ }^{1438}$ facturing system and to lead to a higher probability of EI adoption. 1439 Our results seem to add some more information about the mod- 1440 erating role of participative industrial relations. At firm level it is ${ }^{1441}$ important that management is receptive to union voice, bargain- 1442 ing with unions on innovation issues, in order to turn the 'effect' ${ }^{1443}$ of unions on innovation from negative to positive (Metcalf, 2003), 1444 however even simple top-down information flows from manage- 1445 ment to unions are robustly related to the propensity to innovate. ${ }^{1446}$ This results leave space for further research on the impact of dif- ${ }_{1447}$ ferent models of unions involvement on Els. Finally if we focus our 1448 attention on the results for Els aiming to reduce $\mathrm{CO}_{2}$ emissions, 1449 which largely entails public benefits, unions involvement emerges 1450 as a crucial driver. An industrial-relations driven model behind $\mathrm{CO}_{2} \quad{ }^{1451}$ innovations strongly emerges: this shows a potential important role $\quad{ }^{1452}$ 
of firm level unions in the diffusion of EIs that incorporate large public benefits. Putting it another way, firm level unions could be key players in mitigating private under-investments in EIs, mostly when there is a need to support and define innovations which produce public good benefits. This should be (part of) the social role of unions. Future research, through a more detailed definitions of EIs and of unions involvement models could shed more light on this potential unions role, which opens windows on 'industrial relations' driven Corporate Social Responsibility strategies.

\section{Conclusions}

We analysed the role of unionisation and union involvement in manufacturing firms in relation to the propensity to introduce environmental innovation. The economics, social and policy relevance relates to the active role of unions as innovation players in realities where small and medium firms prevail, which is the case of many industrial contexts. Those economic realities are as much as important as Corporate/MultiNationalEnterprises to cope with the green economy and sustainability challenges. Unionisation does not seem to play a role per se as a 'determinant' of EI: firms with union representatives do not have a higher propensity to innovate in the 'green' area.

However, when we analyse the role of the industrial relations climate at the firm level, focusing our attention on the sub-sample of firms with union representatives, we find some strong linkages between some types of unions involvement and EIs. In particular, the strongest relationships emerge with the adoption of $\mathrm{CO}_{2}$ emissionsreduction technologies and with EMAS and ISO adoption, the two more complex EIs in terms of technological and organisational capability development within a firm. We can speculate that participatory governance may be helpful in augmenting the competencies, including external ones, and the absorptive capacity that firms need to adopt $\mathrm{CO}_{2}$ emissions-reduction technologies. In these cases, a ' $\mathrm{U}$ shaped' relationship emerges: simply informing unions (managerially driven approach to adopting EIs) or bargaining with them on strategic decisions concerning innovation (industrial-relations driven approach to introducing EIs) are positively related to probability of EI adoption, while consulting with unions is not associated with EI adoption (compared to the baseline case of no-involvement).

The evidence is not trivial and original with respect to past studies in this realm: we cannot simply state that a higher degree of union involvement increases the probability of adopting EIs, as we observe a non-linear relationship.

Two competing models of taking strategic decisions at the firm level are found in the analysed firms: a managerially driven approach (informing unions) and a more participation-driven model (bargaining with unions). The two models have different implications for managers and policy makers. On the one hand, it appears that management of manufacturing firms has the required capabilities and knowledge to address innovative challenges without union involvement. On the other hand, we can also argue that participatory governance seems to be effective solutions to the some of the innovative challenges. The role of social dialogue at the firm level is an important driver of EIs and should be taken into account by both policy makers and relevant stakeholders, also because of the role unions could have, through a participative environment, in mitigating the private under-investment in Els with entails large public benefits. Against the challenges posed by environmental policies and green market developments there is a need to invest in new competences and skills at all levels of firms organisation: managers, workers, union's representatives. Effective and performance oriented industrial relations largely derive from the co-presence of adequate skills, which may be lacking in front of new (environmental) strategies.
Finally, some limitations and further research lines can be listed. One of the main limitations is the lack of panel data availability, which could have provided the opportunity to exploit the longitudinal structure of the panel in order to properly deal with the endogeneity issue. Another limit we here acknowledge concerns again the data. Both on the side of EIs and of unions involvement it might be possible to retrieve more detailed information, possibly not only from a single source (e.g. both from management and union representatives). This would help in refining the analysis and focusing the attention on specific linkages among unions involvement, green innovations and green practices. As a last remark on the possibility to extend the present research, we would like to draw the attention on a further potential step that integrates in the framework of the analysis here presented the labour productivity, the employment and also the skill content of the workers' jobs/tasks, which may be influenced by the EIs adoption, with an important role of unions involvement at firm level as a mediating factor.

\section{Appendix A}

Selected questions to depict the information collected for the EI and UNION variables. The answers refer to the period 2006-2008.

\section{ENVIRONMENTAL INNOVATION (EI)}

Q1: Did the firms adopt "environmental" products and/or process technological innovations that induced the following benefits?

\begin{tabular}{l} 
Yes/No \\
\hline
\end{tabular}

1. Reduction in the use of materials and/or energy per output unit (including recycling).

2. $\mathrm{CO}_{2}$ emissions reduction.

3. Emission reductions that improve the quality of soil, water and air.

ENERGY $=1$ if Reduction in the use of materials and/or energy per output unit (included recycling) was marked Yes, 0 otherwise

$\mathrm{CO}_{2}=1$ if $\mathrm{CO}_{2}$ emissions reduction was marked Yes, 0 otherwise

EMISSIONS $=1$ if Emission reductions that improve the quality of soil, water and air, 0 otherwise

Q2: Does the firm employ procedures that structurally identify its environmental performance?

Procedure
1. EMAS
2. ISO 14001
3. Others such as LCA, ISO14040, ......(specify)
EMASISO $=1$ if EMAS or ISO14001 or Others is marked Yes, 0
otherwise
otherwise

UNIONISATION AND INDUSTRIAL RELATIONS

Q3: Do you have union representatives at the firm level: $\square$ Yes $\square$ No

Q4: Were the union representatives involved in the following issues?

\begin{tabular}{lcccc}
\hline Issues & Not involved & Informed & Consulted & Bargained with \\
\hline $\begin{array}{l}\text { 1. Organisational } \\
\text { Innovations }\end{array}$ & $\square$ & $\square$ & $\square$ & $\square$ \\
\hline 2. Training & $\square$ & $\square$ & $\square$ & $\square$ \\
\hline $\begin{array}{l}\text { 3. Technological } \\
\text { Innovation }\end{array}$ & $\square$ & $\square$ & $\square$ & $\square$ \\
\hline $\begin{array}{l}\text { 4. ICT implemen- } \\
\text { tation }\end{array}$ & $\square$ & $\square$ & $\square$ & $\square$ \\
\hline $\begin{array}{l}\text { 5. Environmental } \\
\text { Innovation }\end{array}$ & $\square$ & $\square$ & $\square$ & $\square$ \\
\hline $\begin{array}{l}\text { 6. Internationali- } \\
\text { sation Strategies }\end{array}$ & $\square$ & $\square$ & $\square$ & $\square$ \\
\hline
\end{tabular}

For each firm UNIONINV $=$ Mean of $\sum_{i}\left(J_{i}\right)$ where $J_{i}=\frac{\sum_{i} \text { (Innovation-strategies-ticked) }}{\left.\sum \text { (All-possible-innovation-strategies }\right)}$ with $i=$ Information, Consultation, Bargaining respectively 


\section{Appendix B}

Table B1

Distribution by sector, size and geographical location of population and sample firms.

\begin{tabular}{|c|c|c|c|c|c|c|c|c|}
\hline Sectors & Freq. & Percent & Size & Freq. & Percent & Province & Freq. & Percent \\
\hline \multicolumn{9}{|l|}{ Population } \\
\hline CokeChemical & 130 & 3.2 & $20-49$ & 2720 & 66,86 & Out region & 91 & 2.24 \\
\hline Food & 382 & 9.39 & $50-99$ & 726 & 17,85 & BO & 904 & 22.22 \\
\hline Machinery & 1387 & 34.1 & $100-249$ & 414 & 10,18 & $\mathrm{FC}$ & 346 & 8.51 \\
\hline Metallurgy & 883 & 21.71 & $250+$ & 208 & 5,11 & $\mathrm{FE}$ & 196 & 4.82 \\
\hline NonMetallic & 285 & 7.01 & & & & MO & 891 & 21.9 \\
\hline PaperPrinting & 197 & 4.84 & & & & PC & 200 & 4.92 \\
\hline Shoes & 236 & 5.8 & & & & PR & 381 & 9.37 \\
\hline Textile & 119 & 2.93 & & & & RA & 229 & 5.63 \\
\hline \multirow[t]{2}{*}{ WoodRubberPlasticOther } & 449 & 11.04 & & & & $\mathrm{RE}$ & 667 & 16.4 \\
\hline & & & & & & RN & 163 & 4.01 \\
\hline Total & 4068 & 100 & & 4068 & 100 & & 4068 & 100 \\
\hline \multicolumn{9}{|l|}{ Sample } \\
\hline CokeChemical & 28 & 5.05 & $20-49$ & 208 & 37,48 & Out region & 20 & 3.6 \\
\hline Food & 49 & 8.83 & $50-99$ & 193 & 34,77 & BO & 115 & 20.72 \\
\hline Machinery & 232 & 41.8 & $100-249$ & 96 & 17,30 & FC & 40 & 7.21 \\
\hline Metallurgy & 94 & 16.94 & $250+$ & 58 & 10,45 & FE & 30 & 5.41 \\
\hline NonMetallic & 42 & 7.57 & & & & MO & 124 & 22.34 \\
\hline PaperPrinting & 19 & 3.42 & & & & PC & 25 & 4.5 \\
\hline Shoes & 12 & 2.16 & & & & PR & 49 & 8.83 \\
\hline Textile & 23 & 4.14 & & & & $\mathrm{RA}$ & 32 & 5.77 \\
\hline \multirow[t]{2}{*}{ WoodRubberPlasticOther } & 56 & 10.09 & & & & $\mathrm{RE}$ & 96 & 17.3 \\
\hline & & & & & $\nabla$ & RN & 24 & 4.32 \\
\hline Total & 555 & 100 & & 555 & 100 & & 555 & 100 \\
\hline
\end{tabular}

Table B2

Unionisation by size and sector

\begin{tabular}{llll}
\hline & Union & & \\
\hline Size & 0 & 1 & Total \\
$0: 20-49$ & 101 & 102 & 203 \\
$1: 50-99$ & 40 & 137 & 177 \\
$2: 100-249$ & 11 & 95 & 106 \\
$3: \geq 250$ & 1 & 68 & 69 \\
Total & 153 & 402 & 555 \\
Sectors & 0 & 1 & Total \\
Food & 8 & 41 & 49 \\
Textile & 11 & 12 & 23 \\
Shoes & 2 & 10 & 12 \\
WoodRubberPlasticOther & 13 & 43 & 56 \\
PaperPrinting & 7 & 12 & 19 \\
CokeChemical & 6 & 22 & 28 \\
NonMetallic & 6 & 36 & 42 \\
Metallurgy & 33 & 61 & 94 \\
Machinery & 67 & 165 & 232 \\
Total & 153 & 402 & 555 \\
\hline
\end{tabular}

Table B3

Unions involvement modalities on Els.

\begin{tabular}{llll}
\hline & UnionBargEI & & \\
\hline UnionInfoEI & 0 & 1 & Total \\
0 & 151 & 27 & 178 \\
1 & 224 & 0 & 224 \\
Total & 375 & 27 & 402 \\
& & & \\
& UnionConsEI & & Total \\
\hline UnionInfoEI & 0 & 1 & 178 \\
0 & 101 & 77 & 224 \\
1 & 224 & 0 & 402 \\
Total & 325 & 77 & \\
& & & \\
& UnionConsEI & & Total \\
\hline UnionBargEI & 0 & 1 & 375 \\
0 & 298 & 77 & 27 \\
1 & 27 & 0 & 402 \\
Total & 325 & 77 &
\end{tabular}


Gilli, M., Mancinelli, S., Mazzanti, M., 2014, Jul. Innovation complementarity and environmental productivity effects: reality or delusion? Evidence from the EU. Ecol. Econ. 103, 56-67.

Antonioli, D., Borghesi, S., Mazzanti, M., 2016. Are regional systems greening the economy? Local spillovers, green innovations and firms' economic performances. Econ. Innov. New Technol. (forthcoming).

Antonioli, D., Mancinelli, S., Mazzanti, M., 2013, May. Is environmental innovation embedded within high-performance organisational changes? The role of human resource management and complementarity in green business strategies. Res. Policy 42 (4), 975-988.

Antonioli, D., Manzalini, R., Pini, P., 2011, May. Innovation, workers skills and industrial relations: empirical evidence from firm-level Italian data. J. Socio-Econ. 40 (3), 312-326.

Antonioli, D., Mazzanti, M., Pini, P., 2009, May. Innovation, working conditions and industrial relations: evidence for a local production system. Econ. Ind. Democr. 30 (2), 157-181.

Barbieri, N., Ghisetti, C., Gilli, M., Marin, G., Nicolli, F., 2016. A survey of the literature on environmental innovation based on main path analysis. J. Econ. Surv. (forthcoming).

Barrett, S., 2006, May. Climate treaties and "breakthrough" technologies. Am. Econ. Rev. 96 (2), 22-25.

Berrone, P., Fosfuri, A., Gelabert, L., Gomez-Mejia, L., 2013. Necessity as the mother of green inventions: institutional pressures and environmental innovations. Acad. Manage. J. 34, 891-909.

Borghesi, S., Cainelli, G., Mazzanti, M., 2015. Linking emission trading to environmental innovation: evidence from the Italian manufacturing industry. Res. Policy 44 (3), 669-683.

Borghesi, S., Crespi, F., D’Amato, A., Mazzanti, M., Silvestri, F., 2015. Carbon abatement, sector heterogeneity and policy responses: evidence on induced eco innovations in the EU. Environ. Sci. Pol. 54, 377-388.

Bradley, D., Kim, I., Tian, X., 2015. Do unions affect innovation?. Manag. Sci. (forthcoming)

Cainelli, G., Mazzanti, M., Montresor, S., 2012, Nov. Environmental innovations, local networks and internationalization. Ind. Innov. 19 (8), 697-734.

Carrillo-Hermosilla, J., Del Río, P., Könnölä, T., 2010. Diversity of eco-innovations: reflections from selected case studies. J. Clean. Prod. 18 (10-11), 1073-1083.

Chun, D., Chung, Y., Woo, C., Seo, H., Ko, H., 2015. Labor union effects on innovation and commercialization productivity: an integrated propensity score matching and two-stage data envelopment analysis. Sustainability (Switzerland) 7 (5), 5120-5138.

Cooke, P., Uranga, M.G., Etxebarria, G., 1998. Regional systems of innovation: an evolutionary perspective. Environ. Plan. A 30 (1993), 1563-1584.

Corradini, M., Costantini, V., Mancinelli, S., Mazzanti, M., 2014. Unveiling the dynamic relation between $\mathrm{R} \& \mathrm{D}$ and emission abatement. National and sectoral innovation perspectives from the EU. Ecol. Econ. 102, 48-59.

Corsatea, T.D., 2014. Localised knowledge, local policies and regional innovation activity for renewable energy technologies: evidence.

Crossan, M.M., Apaydin, M., 2010. A multi-dimensional framework of organizational innovation: a systematic review of the literature. J. Manag. Stud. 47 (6), 11541191.

Dangelico, R.M., 2015. Green product innovation: where we are and where we are Going. Bus. Strateg. Environ. (forthcoming).

Dangelico, R.M., 2015. Improving firm environmental performance and reputation: the role of employee green teams. Bus. Strateg. Environ. 24, 735-749.

Dangelico, R.M., Pontrandolfo, P., 2010. From green product definitions and classifications to the Green Option Matrix. J. Clean. Prod. 18 (16-17), 1608-1628.

Dangelico, R.M., Pontrandolfo, P., 2015. Being 'green and competitive': the impact of environmental actions and collaborations on firm performance. Bus. Strateg. Environ. 24, 413-430.

Del Río, P., Romero-Jordán, D., Pe nasco, C., 2015. Analysing firm-specific and typespecific determinants of eco-innovation. Technol. Econ. Dev. Econ. 4913, 1-26. (March).

Doloreux, D., 2002. What we should know about regional systems of innovation. Technol. Soc. 24 (3), 243-263.

Doucouliagos, H., Laroche, P., 2013. Unions and innovation: new insights from the cross-country evidence. Ind. Relat. 52 (2), 467-491.

EEA, 2014. Resource-efficient green economy and EU policies. Technical Report 2, European Environmental Agency, Luxembourg.

Eurofound, 2009. Social dialogue and the recession. Technical report, European Foundation for the Improvement of Living and Working Conditions, Dublin.

Fang, T., Ge, Y., 2012. Unions and firm innovation in China: synergy or strife? China Econ. Rev. 23 (1), 170-180.

reeman, R.B., 2007. Searching for the EU social dialogue model. In: Acocella, N., Leoni, R. (Eds.), Social Pacts, Employment and Growth: A Reappraisal of Ezio Tarantelli's Thought. Physica-Verlag, Heidelberg e New York.

Freeman, R.B., Medoff, J.L., 1979. The two faces of unionism. NBER Working Paper Series 364 .

Freeman, R.B., Medoff, J.L., 1984. What Do Unions Do? Basic Books, New York

Frondel, M., Horbach, J., Rennings, K., 2008. What triggers environmental management and innovation? Empirical evidence for Germany. Ecol. Econ. 66 (1) 153-160.
Groenewegen, J., 2006. The evolution of national innovation systems. J. Econ. Issues XL, 277-285.

Grout, P.A.P., 1984. Investment and wages in the absence of binding contracts: a Nash bargaining approach. Econometrica 52 (2), 449-460.

Guan, J., Chen, K., 2012. Modeling the relative efficiency of national innovation systems. Res. Policy 41 (1), 102-115.

Hanna, M., Newman, W.R., Johnson, P., 2000. Linking operational and environmenta improvement through employee involvement. Int. J. Oper. Prod. Manag. 20 (2) $148-165$.

Hirsch, B.T., 2004. What do unions do for economic performance? J. Lab. Res. 25 (3) 415-455.

Horbach, J., 2013, Nov. Do eco-innovations need specific regional characteristics? An econometric analysis for Germany. Jahrbuch fü,r Regionalwissenschaft 34 (1), 23 38.

Horbach, J., Rammer, C., Rennings, K., 2012. Determinants of eco-innovations by type of environmental impact - the role of regulatory push/pull, technology push and

Kemp, R., Pontoglio, S., 2011. The innovation effects of environmental policy instruments - a typical case of the blind men and the elephant? Ecol. Econ. 40 (1) 148-164.

Kesidou, E., Demirel, P., 2012. On the drivers of eco-innovations: empirical evidence from the UK. Res. Policy 41 (5), 862-870.

Lanfranchi, J., Pekovic, S., 2014. How green is my firm? Workers' attitudes and behaviors towards job in environmentally-related firms. Ecol. Econ. 100, 16-29.

Laplante, N., Harrisson, D., 2008. Conditions for the development of trust between managers and union representatives in a context of innovation [Les condition de la confiance entre gestionnaires et représentants syndicaux dans un contexte d'innovations]. Relations Industrielles 63 (1), 85-107+161.

Marin, G., Mazzanti, M., 2013. The evolution of environmental and labor productivity dynamics: sector based evidence from Italy. J. Evol. Econ. 23 (2), 357-399.

Martin, R., 1994. Innovation and industrial relations. In: Dodgson, M., Rothwell, R (Eds.), The Handbook of Industrial Innovation. Edward Elgar., pp. 1-5.

Mazzanti, M., Antonioli, D., Ghisetti, C., Nicolli, F., 2016. Firm Surveys Relating Environmental Policies, Environmental Performance and Innovation. Technical Report OECD.

Mazzanti, M., Zoboli, R., 2009, feb. Environmental efficiency and labour productivity: trade-off or joint dynamics? A theoretical investigation and empirical evidence from Italy using NAMEA. Ecol. Econ. 68 (4), 1182-1194.

Menezes-Filho, N., Van Reenen, J., 2003. Unions and innovation: a survey of the theory and empirical evidence. In: Addison, J., Schnabel, C. (Eds.), Internationa Handbook of Trade Unions. Edward Elgar, Cheltenham.

Metcalf, D., 2003. Unions and productivity, financial performance and investment: international evidence. In: Addison, J., Schnabel, C. (Eds.), International Handbook of Trade Unions. Edward Elgar, Cheltenham.

Murillo-Luna, J.L., Garcés-Ayerbe, C., Rivera-Torres, P., 2008. Why do patterns of environmental response differ? A stakeholders' pressure approach. Strateg. Manag. J. 29 (11), 1225-1240.

Nielsen, P., Lundvall, B.-A., 2003. Innovation, Learning Organizations and Industria Relations. DRUID Working Paper, pp. 03-07.

Popp, D., 2010. Innovation and climate policy. Ann. Rev. Resour. Econ. 2 (1), 275-298.

Qi, G., Zeng, S., Tam, C., Yin, H., Zou, H., 2013. Stakeholders' influences on corporate green innovation strategy: a case study of manufacturing firms in China. Corp. Soc. Responsib. Environ. Manag. 20 (1), 1-14.

Qi, G.Y., Shen, L.Y., Zeng, S.X., Jorge, O.J., 2010. The drivers for contractors' green innovation: an industry perspective. J. Clean. Prod. 18 (14), 1358-1365.

Rennings, K., 2000. Redefining innovation - eco-innovation research and the contribution from ecological economics. Ecol. Econ. 32 (2), 319-332.

Rennings, K., Rammer, C., 2009. Increasing energy and resource efficiency through innovation: an explorative analysis using innovation survey data. Finance a Uve - Czech J. Econ. Financ. 59 (5), 442-459.

Sharif, N., 2006. Emergence and development of the National Innovation Systems concept. Res. Policy 35 (5), 745-766.

Simpson, D., Power, D., Samson, D., 2007. Greening the automotive supply chain: a relationship perspective. Int. J. Oper. Prod. Manag. 27 (1), 28-48.

Triguero, A., Moreno-Mondéjar, L., Davia, M.A., 2013. Drivers of different types of ecoinnovation in European SMEs. Ecol. Econ. 92, 25-33.

Uzzell, D., Ra, N., Räthzel, N., Uzzell, D., Ra, N., 2011, oct. Trade unions and climate change: the jobs versus environment dilemma. Glob. Environ. Chang. 21 (4), 1215-1223.

Veugelers, R., 2012, dec. Which policy instruments to induce clean innovating? Res Policy 41 (10), 1770-1778.

Walsworth, S., 2010. What do unions do to innovation? An empirical examination of the Canadian private sector. Relations Industrielles 65 (4), 543-561.

Wu, G.-C., 2013. The influence of green supply chain integration and environmenta uncertainty on green innovation in Taiwan's IT industry. Int. J. Oper. Prod. Manag. 18 (8), 539-552. market pull. Ecol. Econ. 78, 112-122.
1783 